\title{
Effects of introduced salmonids on macroinvertebrate communities of mountain ponds in the Iberian system of Spain
}

\author{
Carlos Martínez-Sanz*, Francisco García-Criado and Camino Fernández-Aláez \\ Area of Ecology, Faculty of Biology and Environmental Science, University of León, Campus de Vegazana, s/n. \\ C.P. 24071, León, Spain.
}

* Corresponding author: cmars@unileon.es

Received: 21/8/09 Accepted: 6/2/10

\begin{abstract}
Effects of introduced salmonids on macroinvertebrate communities of mountain ponds in the Iberian system of Spain

This study aimed to assess the impact of salmonid stocking on macrobenthic communities in Spanish mountain ponds. Macroinvertebrates were collected with a hand net following a multihabitat, time-limited sampling in eight ponds (four of them stocked with salmonids and four non-stocked) in the Iberian system. A number of macroinvertebrate-based metrics, as well as several physical and chemical variables, were measured and compared between stocked and non-stocked sites. We hypothesised that stocked ponds would have lower abundances and richness of large and mobile taxa and higher amounts of phosphorus in the water column than non-stocked ones. The results proved that macroinvertebrates were adversely affected by salmonid introductions and might be appropriate indicators of this type of impact. Total richness (both measured and estimated) and diversity were significantly lower in disturbed ponds. Coleoptera, Trichoptera and Heteroptera, large and mobile taxa, were particularly sensitive to the impact. No significant differences in nutrients were detected, although total phosphorus concentrations were usually higher in stocked ponds.
\end{abstract}

Key words: Mountain ponds, salmonid introduction, macroinvertebrates, non-parametric estimators.

\section{RESUMEN}

Efectos de la introducción de salmónidos sobre la comunidad de macroinvertebrados de lagunas de montaña del sistema ibérico, España

El objetivo de este estudio fue testar el impacto de la introducción de salmónidos sobre las comunidades de macroinvertebrados de un conjunto de lagunas de montaña en el noreste de la Península Ibérica. Los macroinvertebrados fueron colectados con una red de mano siguiendo un muestreo de tipo multihábitat, con un determinado tiempo limitado de muestreo en ocho lagunas (cuatro de ellas con introducción de salmónidos y otras cuatro sin dicho impacto) del sistema ibérico. Se compararon características físicas, variables químicas y atributos de la comunidad de macroinvertebrados entre los dos grupos de lagunas (con introducción y sin introducción de salmónidos). Partimos de la hipótesis de que en aquellas lagunas en las que se habían introducido salmónidos nos encontraríamos con baja abundancia y riqueza de taxones de macroinvertebrados móviles y de gran tamaño, así como de altas concentraciones de fósforo en la columna de agua. Los resultados mostraron que la comunidad de macroivertebrados se vio seriamente afectada por la introducción de salmónidos y que podrían ser indicadores apropiados de ese tipo de impacto. Riqueza total (tanto medida como estimada) y diversidad de macroinvertebrados fueron significativamente más bajas en lagunas en las que se llevó a cabo las introducciones de salmónidos. Coleoptera, Trichoptera y Heteroptera, taxones grandes y móviles, fueron particularmente sensibles a dicho impacto. La concentración de fósforo fue usualmente más elevada en aquellas lagunas que habian sufrido la introducción de salmónidos aunque las diferencias no fueron estadísticamente significativas.

Palabras clave: Lagunas de montaña, introducción de salmónidos, macroinvertebrados, estimadores no paramétricos. 


\section{INTRODUCTION}

One of the most extensive human influences on ecosystems is the introduction of non-native species (Wilcove et al., 1998), as this perturbation is a major threat to native biodiversity (Vitousek et al., 1996; Davis, 2003). This impact is more severe when top predators are introduced into spatially restricted environments such as lakes (Kauffman, 1992). In particular, a number of studies in Europe, North America and Oceania have reported negative consequences of fish introductions on macroinvertebrate populations (Leppä et al., 2003) and communities (Crowder \& Cooper, 1982; Morin, 1984; Mitelbach, 1988; Allan \& Flecker, 1993; Diehl \& Eklöv, 1995; Kornijów, 1997; Lodge et al., 1998). Salmonids are size-selective predators, and their introduction into previously fishless alpine lakes in North America and Europe has resulted in the local decline or elimination of large-bodied macroinvertebrates (Wurtsbaugh, Brocksen \& Goldman, 1975; Angradi \& Griffith, 1990; Larson et al., 1992; Liss et al., 1995; Carlisle \& Hawkins, 1998; Drake \& Naiman, 2000). Moreover, they also may have strong effects on ecosystem function (Eby et al., 2006; Simon \& Townsend, 2003), enhancing, for example, phosphorus recycling from the littoral to the pelagic zone (Leavitt et al., 1994; Schindler et al., 2001).

Stocking with salmonids has also been a common practice in Spanish mountain lakes for several decades. However, the consequences of these introductions on the ecosystem have seldom been studied. There is some evidence of the effects on amphibians (Martínez-Solano et al., 2003), but none regarding the response of the macroinvertebrate community.

The aim of this study was to compare the littoral macroinvertebrate community and the values of some chemical variables in salmonidstocked and non-stocked mountain ponds in the Iberian System. We predicted that ponds stocked with salmonids would have lower abundances and richness of large and mobile macroinvertebrates and higher amounts of phosphorus in the water column than non-stocked ponds. The importance of studies like this is strengthened by

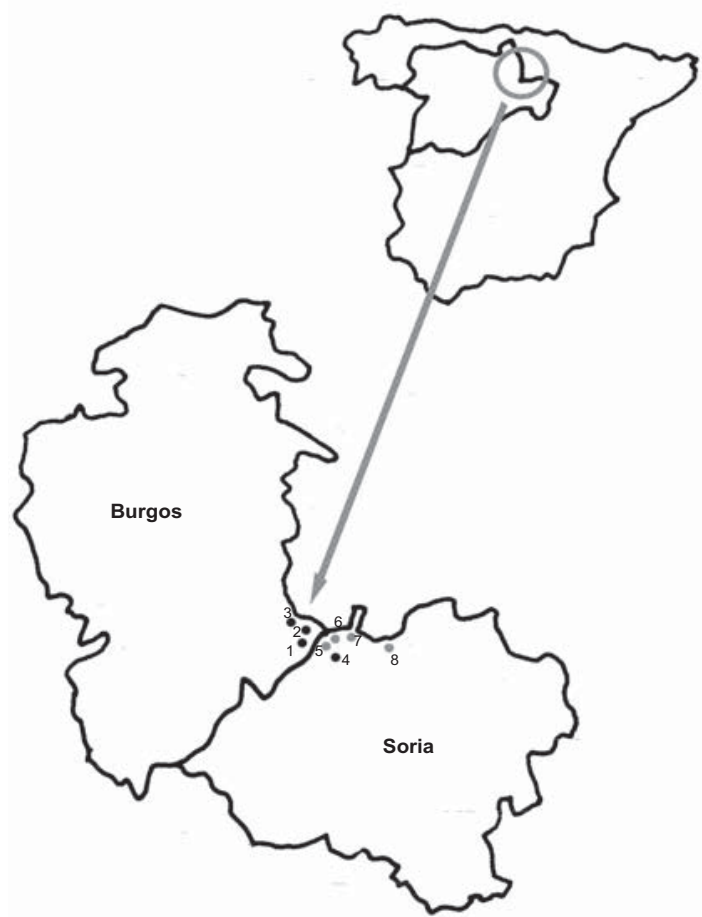

Figure 1. Study area. Black points represent stocked ponds and white points represent non-stocked ponds. Ponds: 1. Patos, 2. Brava, 3. Negra de Neila, 4. Negra de Urbión, 5. Helada, 6. Larga, 7. Verde and 8. Cebollera. Área de estudio. Puntos negros: lagunas "impactadas" (S) y puntos blancos: lagunas "sin impactar" (NS). Lagunas: 1. Patos, 2. Brava, 3. Negra de Neila, 4. Negra de Urbión, 5. Helada, 6. Larga, 7. Verde y 8. Cebollera.

the current need to implement the Water Framework Directive (European Council, 2000). Water bodies are to be classified on the basis of their ecological status using quality elements, including benthic invertebrates. In this context, it is essential to know the effect of salmonid introductions, which are one of the most widespread impacts in North Spanish mountain lakes.

\section{MATERIALS AND METHODS}

\section{Study area}

Eight permanent ponds located in the Iberian System (north-central Spain) were included in this study (Fig. 1). They are all similar in origin (glacial), catchment geology (siliceous), substratum (mostly sandy or stony) and altitude (Ta- 
Table 1. Some characteristics of the ponds included in the study. Chlorophyll a concentration (Chl. a), total nitrogen (TN), soluble reactive phosphorus (SRP) and total phosphorus (TP). Características de las lagunas incluidas en este estudio. Concentración de clorofila a (Chl. a), nitrógeno total (TN), ortofosfato (SRP) y fósforo total (TP).

\begin{tabular}{|c|c|c|c|c|c|c|c|c|c|c|c|c|c|}
\hline Ponds & Stocked & $\begin{array}{l}\text { Altitude } \\
\text { (m.a.s.l.) }\end{array}$ & $\begin{array}{c}\text { Surface } \\
\text { (ha) }\end{array}$ & $\begin{array}{l}\text { Max. depth } \\
\text { (m) }\end{array}$ & $\begin{array}{c}\text { hydrophytes } \\
(\%)\end{array}$ & Chl. a & Secchi & $\begin{array}{l}\text { Conductivity } \\
(\mu \mathrm{S} / \mathrm{cm})\end{array}$ & pH & $\begin{array}{c}\text { Nitrate } \\
(\mathrm{mg} / \mathrm{l})\end{array}$ & $\begin{array}{c}\text { NT } \\
(\mathrm{mg} / \mathrm{l})\end{array}$ & $\begin{array}{l}\text { PRS } \\
(\mu \mathrm{g} / \mathrm{l})\end{array}$ & $\begin{array}{l}\text { PT } \\
(\mu \mathrm{g} / \mathrm{l})\end{array}$ \\
\hline Los Patos & Yes & 1870 & 2.9 & 2 & 1 & 3.6 & 120 & 9.5 & 6.2 & 0.12 & 0.33 & 10.46 & 115.77 \\
\hline Brava & Yes & 1860 & 1.3 & 5.5 & 1 & 0 & 280 & 6.3 & 6.01 & 0.004 & 0.32 & 4.53 & 7.41 \\
\hline Negra Neila & Yes & 1900 & 11.8 & 4.7 & 3 & 3.2 & 210 & 8.7 & 6.5 & 0.17 & 0.25 & 9.90 & 36.05 \\
\hline Negra Urbión & Yes & 1750 & 3.3 & 9 & 3 & 5 & 200 & 18 & 6.53 & 0.002 & 0.31 & 18.97 & 46.55 \\
\hline Verde & No & 1910 & 1.6 & 2 & 1 & 0 & 200 & 18.3 & 6.7 & 0.002 & 0.21 & 4.81 & 4.81 \\
\hline Larga & No & 2010 & 1.0 & 2 & 15 & 20.92 & 200 & 4.17 & 5.44 & 0.16 & 0.22 & 7.86 & 13.18 \\
\hline Helada & No & 2000 & 5.1 & 3 & 10 & 3.1 & 150 & 6.11 & 6.07 & 0.009 & 0.49 & 4.35 & 11.53 \\
\hline Cebollera & No & 1850 & 3.31 & 1.2 & 15 & 10.33 & 120 & 13 & 6.1 & 0.009 & 0.48 & 12.93 & 50.01 \\
\hline
\end{tabular}

ble 1). Only some differences in size and depth were found between the ponds. Negra de Neila pond is 11.8 hectares, a slightly higher area than the other (on average 2.7 hectares), and is 9 meters deep, which is also slightly higher than the rest of study ponds (on average 2.9 meters). Table 1 also shows some morphometrics, chemical and physical characteristics of study ponds, as well as visual estimation of the percentage of coverage of aquatic hydrophytes.

According to the regional administration, four of the ponds (Patos, Brava, Negra de Neila, Negra de Urbión) were repeatedly stocked between 1976 and 1995 with brown trout (Salmo trutta) and rainbow trout (Oncorhynchus mykiss) to support recreational angling (Martínez-Solano, 2003). There are not precise data available about the numbers or biomass of fish introduced per pond and year. As an illustrative example, two of these ponds (Patos \& Brava) were stocked during that period with a total of $69000 \mathrm{~kg}$ of salmonids (3450 kg/yr on average). In the absence of more accurate information, we have divided the studied ponds into two categories: 1) ponds that have not been stocked, or "non-stocked ponds" (Cebollera, Helada, Larga and Verde) and 2) ponds that have been stocked at least once, or "stocked ponds" (Brava, Patos, Negra de Neila, Negra de Urbión).

\section{Sampling}

All of the ponds were sampled once in June 2004 (except Cebollera, which was sampled in June 2006). Three ponds, Patos, Brava and Helada, were sampled again in either 2005 or 2006. These additional samplings have been used here to check for interannual variability, but not to assess the impact of fish stocking. Secchi depth was measured in the lakes and water samples were taken for analyses in the laboratory of total phosphorus (TP) and soluble reactive phosphorus (SRP).

Benthic macroinvertebrate samples were collected from the littoral zone (from the shore up to 1 meter in depth) with a pond net (FBA standard, mesh size $500 \mu \mathrm{m}$ ) following a multihabitat, time-limited sampling (Collinson et al., 1995; Briers \& Biggs, 2005). Each pond was sampled for three to five minutes depending on the area. Total sampling time was proportionally distributed among the main habitats according to their surface in the pond. To allow for amongsite comparisons, abundance data were standardised to one minute. Macroinvertebrates were separated from the plant material and counted under a binocular microscope $(10 \times)$ and identified by genus except for Oligochaeta (identified to class); Glossiphoniidae, Sphaeriidae, Leptophlebiidae, Aeshnidae (to family), Diptera (to subfamily) and Limnephilidae (identified to tribe).

\section{Metric selection and data analysis}

We used a diverse selection of metrics to assess the effects of salmonid introductions on mountain ponds of the study area. We calculated the total abundance and richness of the community as well as the total and percentage abundance and richness of the most relevant taxa. Diversity was estimated using the Shannon Wiener diversity in- 
dex. The taxa were assigned to a trophic group following Tachet et al. (2002), and the percentages of trophic groups were calculated. The list of metrics tested in this study is available in Table 2.

Although species richness is a natural measure of diversity, it is an elusive quantity to measure properly (May, 1988). Only an exhaustive sampling inventory can directly appraise true richness. Nevertheless, in practice, such sampling inventory can rarely be managed due to the limitations of time and money. For this reason, we used non-parametric estimations of species richness (chao 1 and jackknife 1) (Chao, 1987; Heltshe \& Forester, 1983) together with the original measured richness. Non-parametric estimators are sampling theoretic extrapolation methods that only require the number of samples in which each species is found, rather than any parametric information about their abundance. Chao 1 and jackknife 1 are designed to estimate richness from single samples, whereas all other non-parametric estimators require several samples. All non-parametric estimators were calculated over 50 randomised iterations of the species accumulation using EstimateS ver 8 .

The responses of the indices to the impact were graphically explored by means of box-plots showing mean value, standard error and standard deviation of the metrics within each pond category (stocked and non-stocked). One-way analysis of variance (ANOVA) was applied to detect significant differences $(p<0.05)$. The assumptions of normality and variance homogeneity were tested using the Kolmogorov-Smirnov and Levene's tests, respectively. Metrics that did not fulfil the assumptions of ANOVA were either logtransformed (absolute abundance and richness measures) or were transformed using the formula $\sin ^{-1}(x / 100)^{\frac{1}{2}}$. The statistical processing was performed with the STATISTICA 6.0 package.

Table 2. Values of the metrics measured in each pond. Only metrics presented in box-plots are included. Valores de las variables medidas en cada laguna. Sólo son incluidas aquellas representadas en los box-plots.

\begin{tabular}{|c|c|c|c|c|c|c|c|c|}
\hline & Patos & Brava & Negra Neila & Negra Urbión & Verde & Larga & Helada & Cebollera \\
\hline Measured richness & 6 & 8 & 7 & 10 & 16 & 21 & 23 & 22 \\
\hline Chao 1 richness & 6 & 8 & 7.5 & 11 & 18 & 24 & 26.33 & 29 \\
\hline Jackknife 1 richness & 6 & 7 & 7 & 10 & 16 & 21 & 23 & 22 \\
\hline Total abundance & 787 & 102 & 182 & 2016 & 282 & 1245 & 2373 & 1015 \\
\hline Shannon-Wiener & 1.36 & 2.18 & 1.19 & 1.49 & 3.25 & 3.02 & 2.70 & 1.63 \\
\hline Richness of Odonata & 0 & 0 & 0 & 0 & 1 & 1 & 0 & 5 \\
\hline Richness of Heteroptera & 0 & 0 & 0 & 2 & 2 & 2 & 4 & 1 \\
\hline Richness of Coleoptera & 1 & 1 & 1 & 1 & 4 & 8 & 6 & 5 \\
\hline Richness of Trichoptera & 1 & 2 & 1 & 1 & 2 & 3 & 4 & 2 \\
\hline Richness of Chironomidae & 2 & 3 & 3 & 3 & 3 & 3 & 3 & 3 \\
\hline Absolute abundance of Odonata & 0 & 0 & 0 & 0 & 12 & 19 & 0 & 5.3 \\
\hline Absolute abundance of Heteroptera & 0 & 0 & 0 & 17.5 & 10 & 13 & 56 & 10.3 \\
\hline Absolute abundance of Sialis & 0 & 0 & 0.6 & 0 & 36 & 136 & 27.3 & 6.3 \\
\hline Absolute abundance of Coleoptera & 5.9 & 4.3 & 0.6 & 3.7 & 40 & 465 & 326.7 & 22.7 \\
\hline Absolute abundance of Trichoptera & 1.5 & 7.7 & 1.2 & 0.9 & 18.0 & 122.0 & 67.3 & 0.7 \\
\hline Absolute abundance of Chironomidae & 723 & 82 & 146 & 1985 & 144 & 441 & 489 & 956 \\
\hline Percentage of Odonata & 0 & 0 & 0 & 0 & 4.2 & 1.5 & 0 & 0.7 \\
\hline Percentage of Heteroptera & 0 & 0 & 0 & 0.87 & 3.5 & 1.0 & 2.3 & 1.0 \\
\hline Percentage of Sialis & 0 & 0 & 0.3 & 0 & 12.8 & 10.9 & 1.1 & 0.6 \\
\hline Percentage of Coleoptera & 0.7 & 4.2 & 0.3 & 0.2 & 14.2 & 37.3 & 13.8 & 2.2 \\
\hline Percentage of Trichoptera & 0.2 & 7.5 & 0.6 & 0.1 & 6.4 & 9.8 & 2.8 & 0.1 \\
\hline Percentage of Chironomidae & 91.9 & 80.7 & 80.3 & 98.4 & 51.1 & 35.4 & 20.6 & 94.1 \\
\hline Percentage of collector-filterers & 38.1 & 45.4 & 73.7 & 31.9 & 16.3 & 1.8 & 42.1 & 8.1 \\
\hline Percentage of shredders & 0.3 & 8.4 & 0.9 & 0.2 & 12.8 & 11.2 & 2.9 & 0.2 \\
\hline Percentage of scrapers & 53.8 & 8.4 & 4.6 & 54.9 & 19.9 & 47.9 & 21.7 & 64.9 \\
\hline Percentage of predators & 1.5 & 31.1 & 2.3 & 12.9 & 50.3 & 36.9 & 8.6 & 26.0 \\
\hline Total phosphorus $(\mu \mathrm{g} / \mathrm{l})$ & 115.8 & 7.4 & 36.1 & 46.5 & 4.8 & 13.2 & 11.5 & 50.0 \\
\hline Soluble reactive phosphorus $(\mu \mathrm{g} / \mathrm{l})$ & 10.5 & 4.5 & 9.9 & 18.0 & 4.8 & 7.9 & 4.3 & 12.9 \\
\hline
\end{tabular}



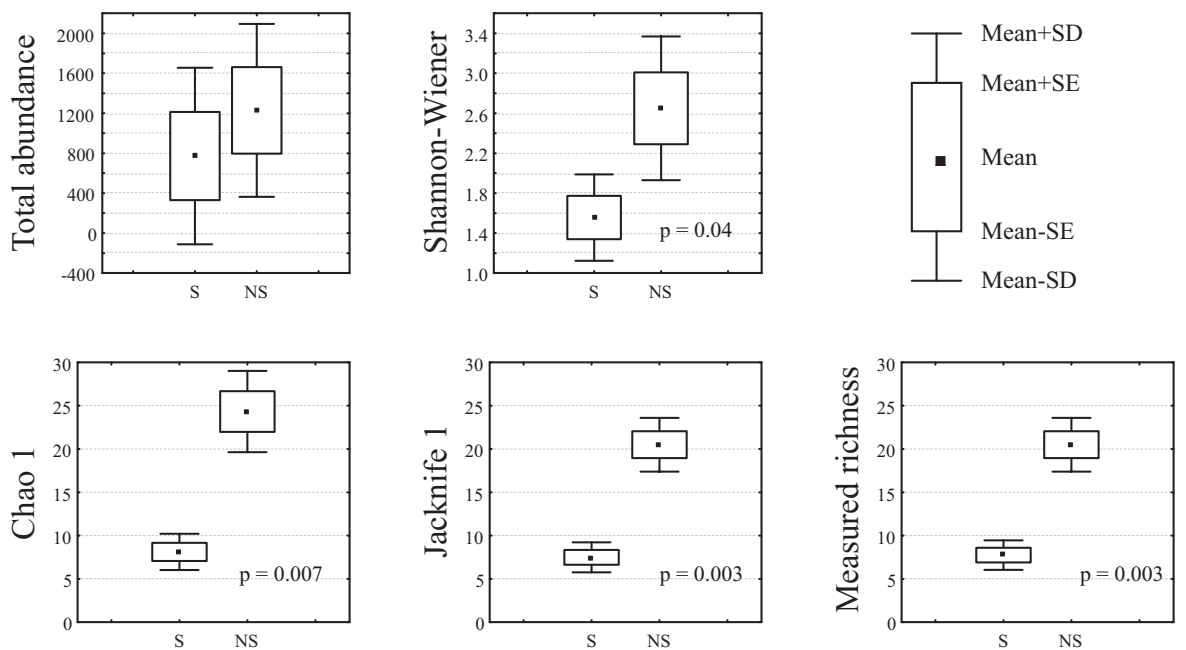

Figure 2. Total abundance, Shannon-Wiener index and richness (both measured and estimated) in stocked (S) and non-stocked (NS) ponds. Abundancia total, índice Shannon-Wiener y Riqueza (tanto medida como estimada) en lagunas "impactadas" (S) y lagunas "sin impactar" (NS).

It would be desirable to check the consistency of the results by repeating the previous analyses in different years, but only three ponds were sampled twice. Instead, we have used the available information to assess the within-lake, interannual variability in the metric values by calculating coefficients of variation. If the variability in the community is low, we may assume that the differences between stocked and non-stocked ponds will essentially remain unchanged.

\section{RESULTS}

\section{Response of the metrics}

Figures 2-5 show the differences between stocked and non-stocked ponds. Taxa and indices significantly differing between pond types are represented. In addition, attributes showing non-significant differences have been included in order to keep potentially useful information. The values of these indices in each pond are presented in Table 2.

The macroinvertebrate community as a whole was negatively affected by salmonid introductions, as deduced from the comparative richness (both measured and estimated) and Shannon index in stocked ponds. Total abundance also showed low values in stocked ponds but differences were only statistically significant for the Shannon index $(p=0.04)$ and richness (Fig. 2). In fact, total richness was the metric most severely affected by the impact. The values of measured richness in non-stocked ponds ranged from 16 to 22 taxa (Table 2) while stocked ponds supported impoverished communities (from 6 to 10 taxa). The estimation provided by chao 1 and jackknife 1 seemed to indicate that the actual richness was very close to the measured values in most of the sites. Jackknife 1 provided estimated richness values equal to those measured while chao 1 estimations were equal (two ponds) or slightly higher (five ponds) than the measured richness. Only in Cebollera were the values notably divergent (22 against 29) (Table 2). In all the cases (measured richness, chao 1 and jackknife 1), differences between stocked and non-stocked ponds were statistically significant $(p=0.003$, $p=0.0007$, and $p=0.003$, respectively).

Coleoptera, Heteroptera and Trichoptera proved to be sensitive to salmonid stocking, as revealed by the low values of abundance (individuals/minute sampling), percentage abundance and richness (Fig. 3). The differences shown by the box-plots were statistically significant (Coleoptera richness $(p=0.001)$, \% He- 

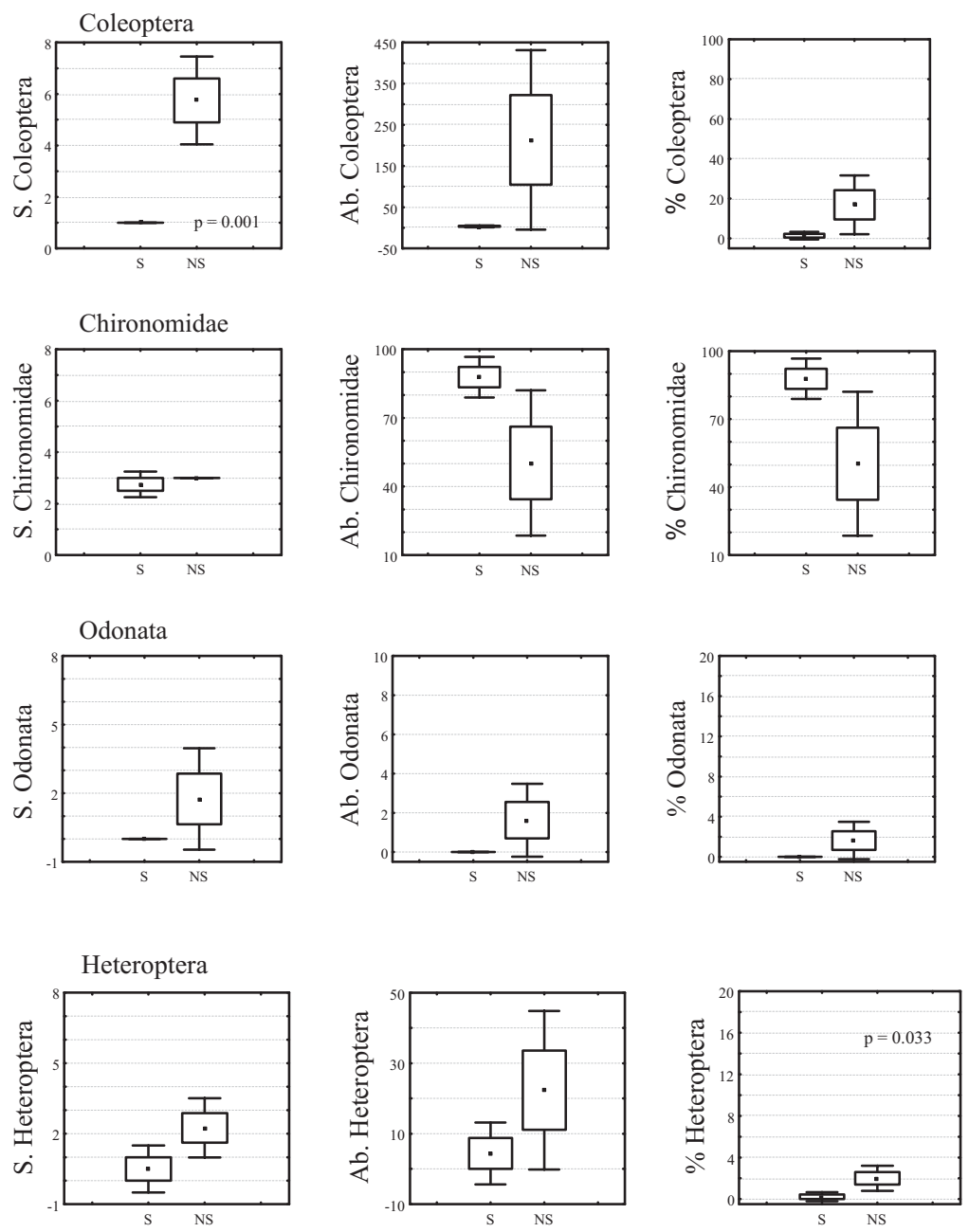

Trichoptera
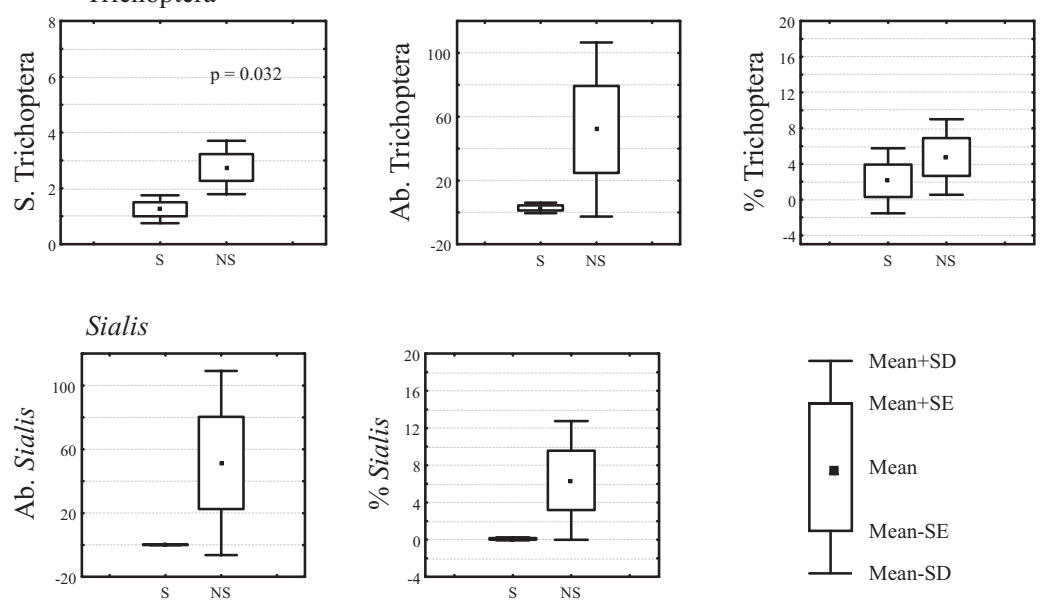

Figure 3. Richness (S), absolute abundance (Ab.) and percentage abundance (\%) of the taxa affected by salmonid introductions. (S) stocked; (NS) non-stocked. Riqueza (S), abundancia absoluta (Ab.) y porcentaje de abundancia (\%) de los taxones afectados por la introducción de salmónidos. Lagunas “impactadas” (S) y lagunas “sin impactar” (NS). 

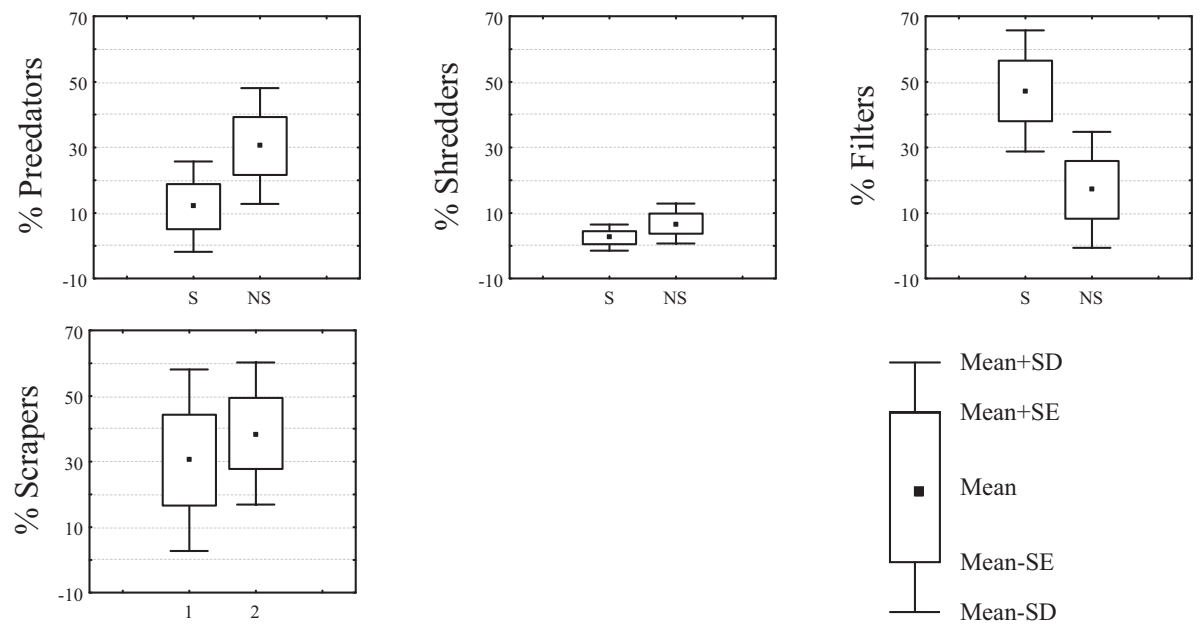

Figure 4. Percentages (\%) of trophic groups in stocked (S) and non-stocked (NS) ponds. Porcentajes (\%) de los grupos tróficos en lagunas “impactadas" (S) y lagunas "sin impactar" (NS).

teroptera $(p=0.033)$ and Trichoptera richness $(p=0.032)$. In contrast, Chironomidae were apparently unaffected and occurred in higher percentages in stocked ponds. On the other hand, the differences were not significant on macroinvertebrate trophic strategy (Fig. 4).

Orthophosphate and total phosphorus did not differ between stocked and non-stocked ponds (Fig. 5), although higher means were observed in stocked ponds.

\section{Interannual variability}

In general, there were only minor tempo$\mathrm{ral} /$ interannual qualitative changes in the community structure and composition, as revealed by the low $\mathrm{CV}$ values of the richness and diversity measures, most of them below $25 \%$ (Ta- ble 3). The CV values of the remaining metrics of the community (absolute and percentage abundance measures) were a bit higher, although usually below $100 \%$ and mostly below $50 \%$, indicating that quantitative changes were also not high. Only rare taxa showed relatively high interannual fluctuations (CV above $100 \%)$ in relative abundances, but this can be considered an expected consequence of the low number of captures.

\section{DISCUSSION}

These results highlight the importance of salmonid stocking as an impact shaping the littoral macroinvertebrate community of Spanish mountain lakes. The predatory activity of salmonids, particularly intense on large and mo-
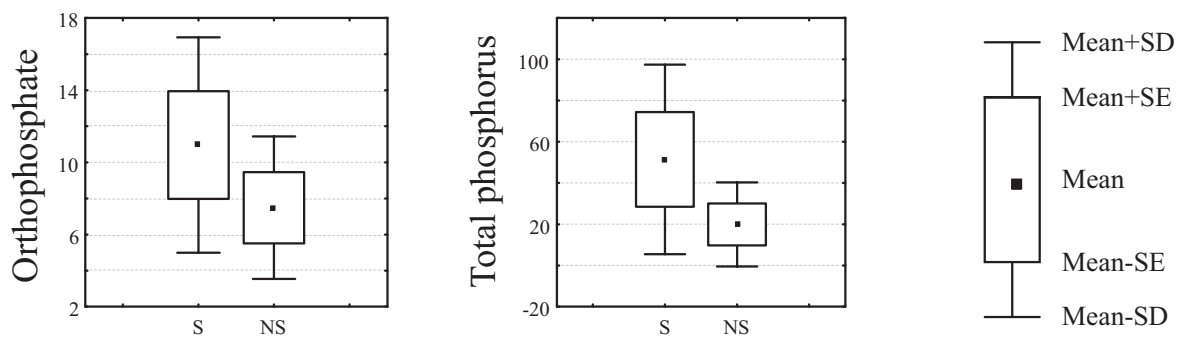

Figure 5. Orthophosphate $(\mu \mathrm{g} / \mathrm{l})$ and total phosphate $(\mu \mathrm{g} / \mathrm{l})$ in stocked (S) and non-stocked (NS) ponds. Ortofosfato ( $\mu \mathrm{g} / \mathrm{l}) \mathrm{y}$ fósforo total $(\mu \mathrm{g} / \mathrm{l})$ tróficos en lagunas "impactadas” (S) y lagunas “sin impactar" (NS). 
Table 3. Interannual variability (coefficient of variation) of the metrics in the ponds sampled for two years. Variabilidad interanual (\% coeficiente de variación) de variables en las lagunas muestreadas dos años.

\begin{tabular}{|c|c|c|c|}
\hline Metric & Patos & Brava & Helada \\
\hline Measured richness & 0 & 22.3 & 3.0 \\
\hline Chao 1 richness & 0 & 22.3 & 3.7 \\
\hline Jackknife 1 richness & 0 & 22.3 & 3.0 \\
\hline Total abundance & 74.9 & 24.9 & 70.2 \\
\hline Shannon-Wiener & 14.9 & 141.1 & 141.1 \\
\hline Richness of Odonata & 0 & 141.4 & 0 \\
\hline Richness of Heteroptera & 0 & 0 & 0 \\
\hline Richness of Coleoptera & 141.4 & 0 & 20.2 \\
\hline Richness of Trichoptera & 47.1 & 28.3 & 20.2 \\
\hline Richness of Chironomidae & 0 & 0 & 0 \\
\hline Absolute abundance of Odonata & 0 & 141.4 & \\
\hline Absolute abundance of Heteroptera & 0 & 0 & 89.8 \\
\hline Absolute abundance of Sialis & 0 & 0 & 73.7 \\
\hline Absolute abundance of Coleoptera & 141.4 & 68.3 & 81.5 \\
\hline Absolute abundance of Trichoptera & 64.3 & 61.4 & 135.3 \\
\hline Absolute abundance of Chironomidae & 83.0 & 16.6 & 3.6 \\
\hline Percentage of Odonata & 0 & 141.4 & 0 \\
\hline Percentage of Heteroptera & 0 & 0 & 25.4 \\
\hline Percentage of Sialis & 0 & 0 & 115.5 \\
\hline Percentage of Coleoptera & 141.4 & 87.0 & 16.0 \\
\hline Percentage of Trichoptera & 110.0 & 39.9 & 122.6 \\
\hline Percentage of Chironomidae & 11.8 & 8.4 & 72.9 \\
\hline Percentage Filterers & 34.5 & 13.3 & 29.9 \\
\hline Percentage Shredders & 125.4 & 23.8 & 22.6 \\
\hline Percentage Scrapers & 0.9 & 56.6 & 37.4 \\
\hline Percentage Predators & 141.4 & 9.3 & 78.7 \\
\hline Total phosphorus (TP) & 65.7 & 84.2 & 47.6 \\
\hline Ortophosphates (RSP) & 68.1 & 50.5 & 24.7 \\
\hline
\end{tabular}

bile taxa, resulted in modifications of the community structure, as previously demonstrated by a number of studies (Carlisle \& Hawkins, 1998; Drake \& Naiman, 2000; Knapp et al., 2001). In the ponds included in the present study, Heteroptera, Coleoptera and Trichoptera were the groups most negatively affected. This selective effect entailed changes in the metrics based on these taxa (reduction of their richness or percentage abundances in stocked ponds), which extended to the whole community, resulting in relatively low values of total richness and diversity (Shannon index). Abundance in stocked ponds was not significantly lower because the dominant taxon in the study area, Chironomidae, was not affected by salmonid predation.

The results obtained could not be tested by repeating the sampling in a different year. However, the low inter-annual variability in the metrics de- tected in three of the ponds (see Kashian \& Burton, 2000 and Trigal et al., 2006 for a comparison of the $\mathrm{CV}$ values) point to probable stability in the community composition among years in both stocked and non-stocked ponds.

The results obtained are not surprising and are in accordance with expectations. However, the consequences of the introductions of salmonids are not always so evident (Wissinger et al., 2006), and several studies have revealed either moderate or no effects of fish predation (Hanson \& Leggett, 1986; Cobb \& Watzin, 1998). There are at least three possible factors that might explain the effects observed in the study area: habitat structure, density of salmonids and the non-native nature of the predator.

Aquatic vegetation often plays an important role in regulating the predator-prey interaction (Jeppesen et al., 1998). The predation effect of 
benthivorous fish is often stabilized by structural complexity, and the incidence on the abundance, body size, diversity and community structure of macroinvertebrates are less pronounced within vegetation stands than in open water (Crowder \& Cooper, 1982; Gilinsky, 1984; Diehl, 1992; Diehl \& Eklöv, 1995; Diehl \& Kornijów, 1997). In addition, numerous laboratory experiments have demonstrated that the rates at which most fish species encounter and attack prey decline with increased density of artificial or natural hydrophytes (Diehl, 1988; Nelson \& Bonsdorff, 1990). Wissinger et al. (2006) compared the benthic invertebrate communities of New Zealand lakes with and without introduced rainbow and brown trout, and all of the large-bodied benthic taxa were present in all the lakes. They hypothesised that the beds of submerged vegetation provided refuge for large macroinvertebrates, resulting in a minimal impact on the community. The ponds in the study, especially stocked ponds, lack submerged vegetation with the exception of sparse shoots of hydrophytes (Ranunculus, Callitriche) (Table 1). The absence of refuge is a reliable explanation for the high intensity of the impact on large bodied macroinvertebrates in the present study.

It is important to consider the density of salmonids after introduction. Knapp et al. (2005) observed that the ratio of the observed number of taxa to that expected to occur in the absence of introduction were inversely related to trout density, presumably because predation pressure increased with fish density (Pierce and Hinrichs, 1997, Leppa et al., 2003). We do not have precise data on salmonid density in the studied ponds; however, the little information available on stocked biomass (around $3500 \mathrm{~kg} /$ year in Brava and Patos together) and the extremely high number of trout observed near the shores (personal observation) make it reasonable to assume an extremely high fish density existed, at least in those two ponds. The absence of density data per pond makes it impossible to check whether there is an inverse correlation between salmonid density and the abundance or richness of macroinvertebrate taxa. Nevertheless, high fish density might be a relevant factor explaining the severe impact observed.
Salmonids are not native predators in the studied ponds (J. C. Pena and B. Fuertes, personal communication), and their effects on native prey may be strong. This idea is supported by several studies that have shown that introduced predators may have particularly strong effects on native prey that do not recognize new predators and thus do not show appropriate avoidance behaviours (Shave et al., 1994, Kiesecker $\&$ Blaustein 1997), or if the introduced predators have foraging strategies that differ from those of native predators (McIntosh \& Townsend, 1996).

The influence of stocking on the chemical characteristics of the water column was less evident. We expected an increase in nutrient concentrations as a consequence of nutrient recycling enhancement (Vannis, 1996; Tátrai et al., 2003) and of the repeated additions of food made by the regional authority to support fish populations. Contrary to expectations, no significant differences were found in phosphorus concentrations between stocked and non-stocked ponds (Fig. 5).

\section{ACKNOWLEDGEMENTS}

This study was partially funded by the Junta de Castilla y León (project UEMC1/04).

\section{REFERENCES}

ALLAN, J. D. \& A. S. FLECKER. 1993. Biodiversity conservation in running waters: identifying the major factors that threaten destruction of riverine species and ecosystems. BioSciece, 43: 32-43.

ANGRADI, T. R. \& J. S. GRIFFITH. 1990. Diel feeding chronology and diet selection of rainbow trout (Oncorhynchus mykiss) in the Henry's Fork of the Snake River, Idaho. Can. J. Fish. Aq. Sci., 47: 199209.

BRIERS, R. A. \& J. BIGGS. 2005. Spatial patterns in pond invertebrate communities: separating environmental and distance effects. Aquatic. Conserv: Mar. Freshw. Ecosyst., 15: 549-557.

CARLISLE, D. C. \& C. P. HAWKINS. 1998. Relationships between invertebrate assemblage structure, 2 trout species, and habitat structure in 
UTA montain lakes. J. North Amer. Benth. Soc., 17(3): 286-300.

CHAO, A. 1987. Estimating the population-size for capture recapture data with unequal catchability. Biometrics, 43: 783-791.

COBB, S. E. \& M. C. WATZIN. 1998. Trophic interactions between yellow perch (Perca flavescens) and their benthic prey in a littoral zone community. Can. J. Fish. Aq. Sci., 55: 28-36.

COLLINSON, N. H., J. BIGGS, A. CORFIELD, M. J. HODSON, D. WHITFIELD \& P. J. WILLIAMS. 1995. Temporary and permanent ponds of drying out on the conservation value of aquatic macroinvertebrate communities. Biol. Conserv., 74: 125-133.

CROWDER, L. B. \& W. E. COOPER. 1982. Habitat structural complexity and the interaction between bluegills and their prey. Ecology, 63: 1802-1913.

DAVIS, M. A. 2003. Biotic globalization: does competition from introduced species threaten biodiversity? BioScience, 53: 481-489.

DIEHL, S. 1988. Foraging efficiency of three freshwater fish: effects of structural complexity and light. Oikos, 53: 207-214.

DIEHL, S. 1992. Fish predation and benthic community structure: the role of omnivory and habitat complexity. Ecology, 73: 1646-1661.

DIEHL, S. \& P. EKLÖV. 1995. Effects of piscivoremediated habitat use on resources, diet and growth of perch. Ecology, 76: 1712-1726.

DIEHL, S. \& R. KORNIJÓW. 1997. Influence of submerged macrophytes on trophic interactions among fish and macroinvertebrates. In: The Structuring Role of Submerged Macrophytes in Lakes. E. Jeppesen, Ma. Søndergaard, Mo. Søndergaard \& K. Christoffersen (eds.): 24-46. Springer, New York, USA.

DRAKE, D. C. \& R. J. NAIMAN. 2000. An evaluation of restoration efforts in fishless lakes stocked with exotic trout. Conserv Biol., 14: 1807-1820.

EBY, L. A., W. J. ROACH, L. B. CROWDER \& J. A. STANFORD. 2006. Effects of stocking-up freshwater food webs. Trends. Ecol. Evol., 21: 576-584.

European Council, 2000. Council of European Communities Directive 2000/60/EEC of 23 October 2000 establishing a framework for community action in the field of water policy. Official Journal of European Communities L327/1.

GILINSKY, E. 1984. The role of fish predation and spatial heterogeneity in determining benthic community structure. Ecology, 65: 455-468.
HANSON, J. M. \& W. C. LEGGETT. 1986. Effect of competition between two freshwater fishes on prey consumption and abundance. Can. J. Fish. Aq. Sci., 43: 1361-1372.

HELTSHE, J. F. \& N. E. FORESTER. 1983. Estimating species richness using the jackknife procedure. Biometrics, 39: 1-11.

JEPPESEN, E., MA. SøNDERGAARD, MO. SØNDERGAARD \& K. CHRISTOFFERSEN. 1998. The Structuring Role of Submerged Macrophytes in Lakes. Springer, New York. 421 pp.

JOHNSON, R. K. 1998. Spatiotemporal variability of temperate lake macroinvertebrate communities: detection of impact. Ecol. Appl., 8: 61-70.

KASHIAN, D. R. \& T. M. BURTON. 2000. A Comparison of Macroinvertebrates of Two Great Lakes Coastal Wetlands: Testing Potential Metrics for an Index of Ecological Integrity. J. Great Lakes Res., 26(4): 460-481.

KAUFFMAN, L. 1992. Catastrophic change in species-rich freshwater ecosystems: the lessons of Lake Victoria. BioScience, 42: 846-858.

KIESECKER, J. M. \& A. R. BLAUSTEIN. 1997. Population differences in responses of red-legged frogs (Rana aurora) to introduced bullfrogs. Ecology, 78: 1752-1760.

KNAPP, R. A., K. R. MATTHEWS \& O. SARNELLE. 2001. Resistance and resilience of alpine lake fauna to fish introductions. Ecol. Monogr., 71: 401-421.

KNAPP, R. A., C. P. HAWKINS, J. LADAU \& J. G. MCCLORY. 2005. Fauna of yosemite national park lakes has low resistance but high resilience to fish introductions. Ecol. Appl., 15(3): 835-847.

KORNIJÓW, R. 1997. The impact of predation by perch on the size- structure of Chironomus larvaethe role of vertical distribution of the prey in the bottom sediments, and habitat complexity. Hydrobiologia, 342-344: 207-213.

LARSON, G. L., A. WONES, D. D. MCINTIRE \& B. A. SAMORA. 1992. Limnology of subalpine lakes and high mountain forest lakes. Mt. Rainier National Park. National Park Service Technical Report OSU/NRTR 92/1. National Park Service, Seattle, WA, U.S.A. 53 pp.

LEAVITT, P. R., D. E. SCHINDLER, A. J. PAUL, A. K. HARDIE \& D. W. SCHINDLER. 1994. Fossil pigment records of phytoplankton in trout-stocked alpine lakes. Can. J. Fish. Aq. Sci., 51: 2411-2423. 
LEPPA, M., H. HAMALAINEN \& J. KARJALAINEN. 2003. The response of benthic macroinvertebrates to whole-lake biomanipulation. Hydrobiologia, 498: 97-105.

LISS, W. J., G. L. LARSON, E. DEIMLING et al. 1995. Ecological effects of stocked trout in naturally fishless high mountain lakes: North Cascades National Park, WA, USA. National Park Service Technical Report NPS/ PNROSU/NRTRR95-03. National Park Service, Pacific Northwest Region, Seattle, WA. 167 pp.

LODGE, D. M., R. A. STEIN, K. M. BROWN, A. P. COVICH, C. BRONMARK, J. E. GARVEY \& S. P. KLOSIEWSKI. 1998. Predicting impact of freshwater exotic species on native biodiversity: challenges in spatial scaling. Aust. J. Ecology., 23: 53-67.

MARTÍNEZ-SOLANO, I., J. BARBADILO, M. LAPEÑA. 2003. Effect of introduced fish on amphibian species richness and densities at a montane assemblage in the Sierra de Neila, Spain. Herpetological J., 13: 167-173.

MAY, R. M. 1988. How many species on earth? Science, 241: 1441-1449.

MCINTOSH, A. R. \& C. R., TOWNSEND. 1996. Interaction between fish, grazing invertebrates and algae in a New Zealand stream: a trophic cascade mediated by fish-induced changes to grazer behaviour? Oecologia, 108: 174-181.

MITTELBACH, G. G. 1988. Competition among refuging sunfishes and effects of fish density on littoral zone invertebrates. Ecology, 69: 614-623.

MORIN, P. J. 1984. The impact of fish exclusion on the abundance and species composition of larval odonates: results of short-term experiments in a North Carolina farm pond. Ecology, 65: 53-60.

NELSON, W. G. \& E. BONSDORFF. 1990. Fish predation and habitat complexity: are complexity thresholds real? J. Exp. Mar. Biol. Ecol., 141: 183194.

PIERCE, C. L. \& B. D. HINRICHS. 1997. Response of littoral invertebrates to reduction of fish density: simultaneous experiments in ponds with different fish assemblages. Freshwater Biol., 37: 397-408.

SCHINDLER, D. E., R. A. KNAPP \& P. R. LEAV-
ITT. 2001. Alteration of nutrient cycle and algal production resulting from fish introductions into mountain lakes. Ecosystems, 4: 301-321.

SHAVE C. R., C. R. TOWNSEND \& T. A. CROWL. 1994. Antipredator behaviours of a freshwater crayfish (Paranephrops zealandicus) to a native and introduced predator. New Zeal. J. Ecol., 18: 1-10.

SIMON, K. S. \& C. R. TOWNSEND. 2003. Impacts of freshwater invaders at different levels of ecological organisation, with emphasis on salmonids and ecosystem consequences. Freshwater Biol., 48: 982-994.

TACHET, H., P. RICHOUX, M. BOURNAUD \& P. USSEGLIO-POLATERA. 2002. Invertébrés d'eau douce. Systématique, biologie, écologie. CNRS EDITIONS, Paris 2000, 2002. 587 pp.

TATRAI, I., K. MATYAS, J. KORPONAI, G. PAULOVITS \& F. PEKAR. 2003. Management of fish communities and its impacts on the lower trophic levels in shallow ecosystems in Hungary. Hydrobiologia, 506-509: 489-496.

TRIGAL, C., F. GARCÍA-CRIADO \& C. FERNÁNDEZ-ALÁEZ. 2006. Among-habitat and temporal variability of selected macroinvertebrate based metrics in a Mediterranean shallow lake (NW Spain). Hydrobiologia, 563: 371-384.

VANNI, M. J. 1986. Fish predation and zooplankton demography. Ecology, 67: 337-354.

VITOUSEK, P. M., C. M. D’ANTONIO, L. L. LOOPE \& R. WESTBROOK, 1996. Biological invasions as global environmental change. Am. Sci., 84: 468-477.

WILCOVE, D. S., D. ROTHSTEIN, J. DUBOW, A. PHILLIPS \& E., LOSOS. 1998. Quantifying threats to imperiled species in the United States. BioScience, 48: 607-615.

WISSINGER, S. A., A. R. MCINTOSH \& H. S. GREIG. 2006. Impacts of introduced brow and rainbow trout on benthic invertebrate communities in shallow New Zealand lakes. Freshwater Biol., 51: 2009-2028.

WURTSBAUGH, W. A., R. W. BROCKSEN \& C. R. GOLDMAN. 1975. Food and distribution of under yearling brook and rainbow trout in Castle Lake, California. Trans. Am. Fish. Soc., 104: 88-95. 